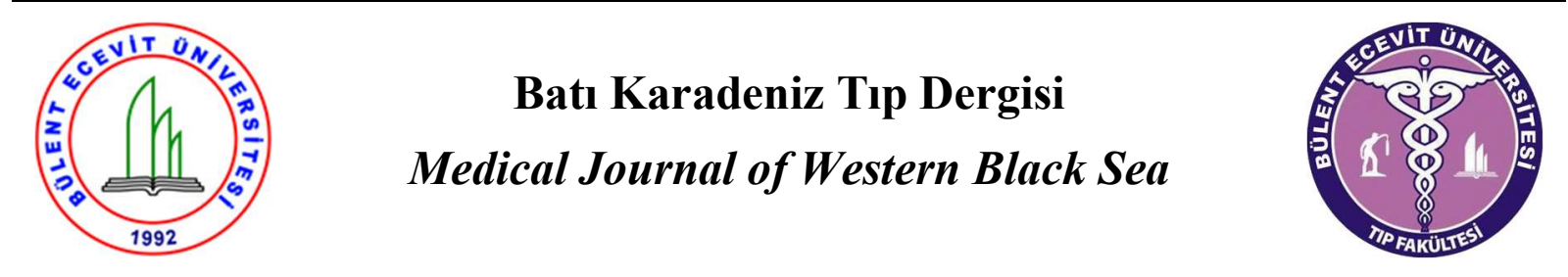

Olgu sunumu

Doi: 10.29058/mjwbs.2019.3.6

\title{
Atipik İzoenzim Paternli Benign Geçici Hiperfosfatazemi Olgu Sunumu
}

\author{
Ahmet Girgeç $^{\mathrm{a}}$, Fatih Temiz ${ }^{\mathrm{a}}$, Sibel Kahraman Girgeç ${ }^{\mathrm{b}}$, Can Acıpayam ${ }^{\mathrm{a}}$ \\ a Kahramanmaraş Sütçü İmam Üniversitesi Tıp Fakültesi, Çocuk Sağlığı ve Hastalıkları Anabilim Dalı, \\ Kahramanmaraş, Türkiye \\ b Zonguldak Bülent Ecevit Üniversitesi Tıp Fakültesi, Ruh Sağlığı ve Hastalıkları Anabilim Dalı, \\ Zonguldak,Türkiye
}

ORCID : Ahmet Girgeç 000000020373 9615, Fatih Temiz 000000022226 0116, Sibel Kahraman Girgeç 000000015277 214X, Can Acipayam 000000026379 224X

\begin{tabular}{|c|c|}
\hline $\begin{array}{l}\text { M A K A L E } \\
\text { B I L G I S I }\end{array}$ & Ö Z \\
\hline $\begin{array}{l}\text { Gönderilme Tarihi: } \\
\text { 29.03.2019 } \\
\text { Revizyon: } \\
\text { 5.12.2019 } \\
\text { Kabul: } \\
\text { 21.12.2019 } \\
\text { Sorumlu Yazar: } \\
\text { Ahmet Girgeç } \\
\text { agirgec01@gmail.com } \\
\text { Anahtar Kelimeler: } \\
\text { Alkalen fosfataz, benign geçici } \\
\text { hiperfosfatazemi }\end{array}$ & $\begin{array}{l}\text { Alkalen fosfataz özellikle ergenlik döneminde artmış büyüme hızı } \\
\text { nedeniyle ve gebelik döneminde ise fetal ve plesental yapıların } \\
\text { üretimindeki artıştan dolayı } 2-3 \text { kat artabilir. Fakat hayatın hiçbir } \\
\text { döneminde benign geçici hiperfosfatazemideki kadar artmaz. Benign } \\
\text { geçici hiperfosfatazemi (BGH), sıklıkla } 5 \text { yaşından küçük } \\
\text { çocuklarda serum alkalen fosfataz düzeyinin (ALP) normal } \\
\text { değerlerin 3-50 kata kadar yüksekliği ile seyreden ve ALP'nin } \\
\text { haftalar veya aylar içinde normale döndüğü benign bir klinik } \\
\text { durumdur. Bu hastalıkta genellikle karaciğer ve kemik kaynaklı ALP } \\
\text { izoenzimleri yükselir, ince barsak izoenzimlerin yükseldiği daha az } \\
\text { görülmüştür. ALP yüksekliği ile başvuran hastalarda karaciğer, } \\
\text { kemik hastalıkları ve maligniteler ekarte edildikten sonra benign } \\
\text { geçici hiperfosfatazemi tanıda akla gelmelidir. Bu yazıda bulantı } \\
\text { kusma nedeniyle takip edilen ve bakılan tetkiklerinde rastlantısal } \\
\text { olarak ALP düzeyinin normalin } 20 \text { katı kadar yüksek olan ve diğer } \\
\text { hastalıklar ekarte edilerek BGH tanısı konulan15 aylık kız hastayı } \\
\text { literatürdeki bilgiler eşliğinde paylaşmak istedik. }\end{array}$ \\
\hline
\end{tabular}




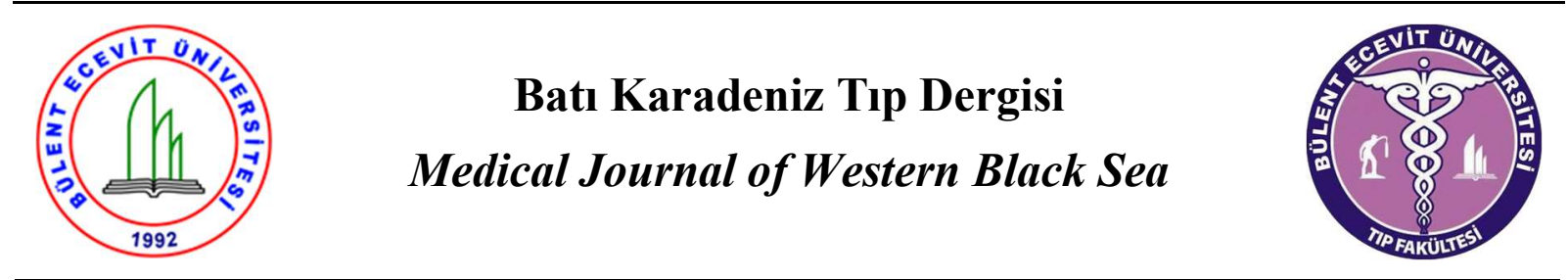

Case report

Doi: $10.29058 /$ mjwbs.2019.3.6

\title{
Benign Transient Hyperphosphatasemia with Atypical İsoenzyme Pattern: A Case Report
}

\author{
Ahmet Girgeç $^{a}$, Fatih Temiz ${ }^{a}$, Sibel Kahraman Girgeç ${ }^{b}$, Can Acıpayam ${ }^{a}$ \\ a Kahramanmaraş Sutcu Imam University School of Medicine, Department of Child Health and Diseases, \\ Kahramanmaras, Turkey \\ ${ }^{\mathrm{b}}$ Zonguldak Bulent Ecevit University School of Medicine, Department of Mental Health and Diseases, \\ Zonguldak, Turkey
}

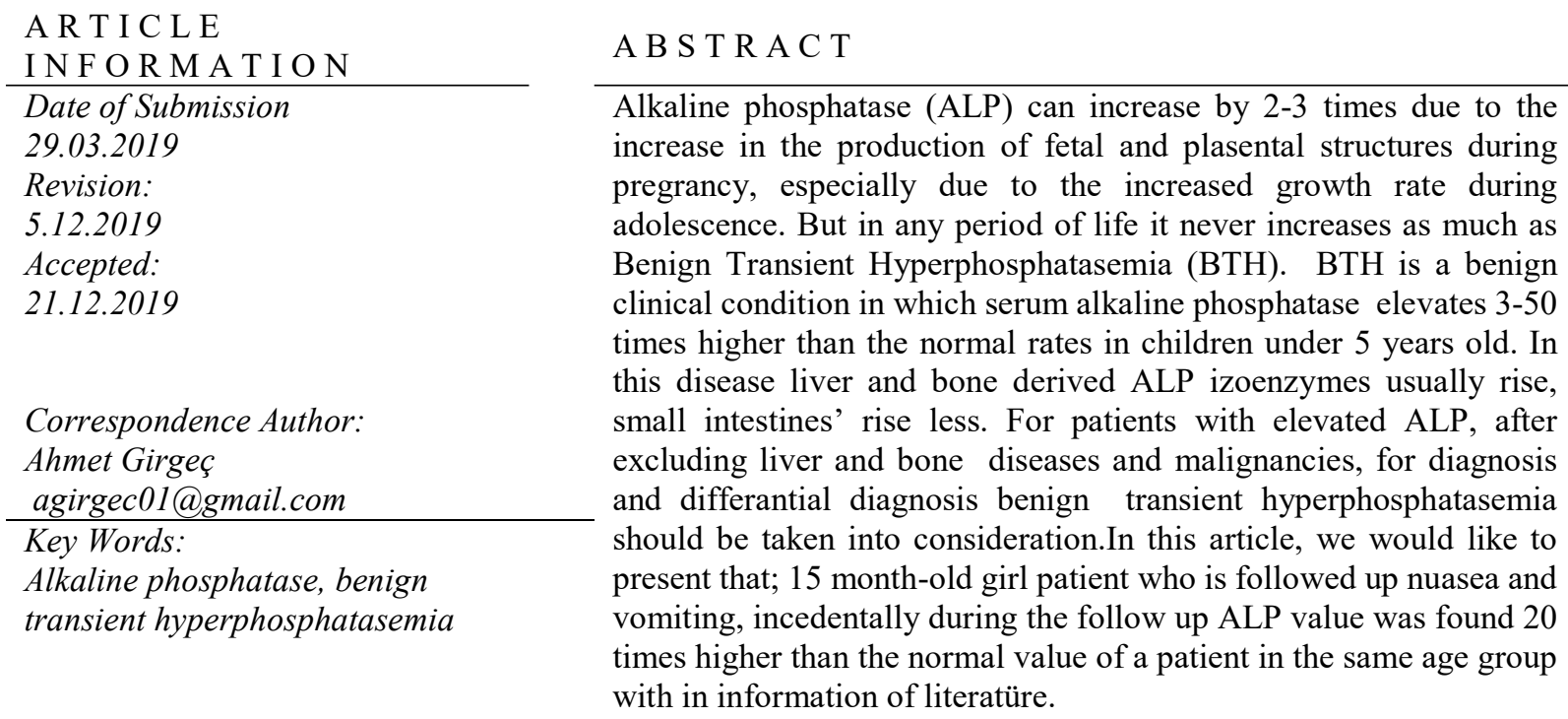

(C) 2019 Bulent Ecevit University All rights reserved. 
Giriş

Benign geçici hiperfosfatazemi (BGH), sıklıkla 5 yaşından küçük çocuklarda kemik, karaciğer ve barsak hastalığ $\breve{1}_{1}$ olmadan serum alkalen fosfataz düzeyinin (ALP) normal değerlerin 3-50 kata kadar yüksekliği ile seyreden ve serum alkalen fosfataz düzeyinin (ALP) haftalar veya aylar içinde normale döndüğü benign bir klinik durumdur (1,2). İnsidans1 \%2.5-5.1 arasında değişmektedir (1). Literatürdeki çalışmaların çoğunda, rastlantısal olarak ALP yüksekliği saptanmıştır. Hastalığın nedeni tam olarak bilinmemekle birlikte, virüsler, akut gastroenterit, solunum sistemi hastalıkları, 1S1 değişimi ve anemi ile ilişkilendirilmiştir (3). Literatürde transplantasyon ve malign hastalıklar ve D vitamini ile ilişkilendirilen çalışmalar da mevcuttur (1). Bu yazıda bulantı kusma nedeniyle takip edilen ve bakılan tetkiklerinde rastlantısal olarak ALP düzeyinin normalin 20 katı kadar yüksek olan, benign geçici hiperfosfatazya tanısı konulan, 15 aylık kız hastayı literatürdeki bilgiler eşliğinde paylaşmak istedik.

\section{Olgu Sunumu}

Daha önce sağlıklı olan 15 aylık kız hasta, yaklaşık 3 gündür bulantı ve kusma şikayetiyle dış merkeze başvurmuş. Diş merkezde bakılan tetkiklerinde ALP düzeyi 4409 IU/L gelince tarafımıza yönlendirilmiş. Hastanın özgeçmişinde herhangi bir ilaç kullanımı ve kronik hastalık öyküsü yoktu.

Soygeçmişinde; sağlıklı anne ve babanın 4 . sağlıklı ve yaşayan çocuğu, anne ve baba arasında 2.derece akrabalık mevcut olup ailede ek hastalık öyküsü yoktu.
Fizik muayenesinde genel durumu iyi vital bulguları stabildi. Vücut ağırlığı $9 \mathrm{~kg}(10-25 p)$, boy $74 \mathrm{~cm}$ (10$25 \mathrm{p}$ ) idi. Tonsiller hiperemik ve hipertrofik olup ön fontanel açıklığı $1 \times 1 \mathrm{~cm}$ olup, sistemik muayenesinde ek patolojik bulguya rastlanmadi. Yapılan tetkiklerinde hemoglobin 12,4 g/dL, lökosit $8,53 \times 109 / \mathrm{mm} 3$, trombosit $343 \times 109 / \mathrm{mm} 3$, CRP $3 \mathrm{mg} / \mathrm{L}$, sedimantasyon $3 \mathrm{~mm} / \mathrm{saat}$, kalsiyum $9,6 \mathrm{mg} / \mathrm{dL}$, fosfor $6 \mathrm{mg} / \mathrm{dL}$, magnezyum $2,07 \mathrm{mg} / \mathrm{dL}$, BUN $10 \mathrm{mg} / \mathrm{dL}$, Kreatinin $0,2 \mathrm{mg} / \mathrm{dL}$, aspartat transaminaz $36 \mathrm{U} / \mathrm{L}(10-48)$, alanin transaminaz 17 U/L (5-25), LDH $225 \mathrm{U} / \mathrm{L}$, ürik asit 2,6 mg/dL, sT4 1,11, TSH $1,52 \mathrm{mIU} / \mathrm{L} \quad(0,7-5,97 \mathrm{mIU} / \mathrm{L}), \quad 25$ OHvitamin-D düzeyi $43 \mathrm{ng} / \mathrm{ml}$ (20-120), Parathormon $41 \mathrm{pg} / \mathrm{mL}$ (15-65 pg/mL) bulundu. Hastada maligniteyi ekarte etmek amaciyla periferik yayma yapıldı: periferik yaymada atipik hücre görülmedi (parçalı \% 29, lenfosit \% 58, monosit \% 8 , eozinofil \%5) olarak değerlendirildi. Çekilen sol el bilek grafisinde rikets bulgusu olmayı, yaşıtlarıyla uyumlu ve normal olarak değerlendirildi. Hastaya batın ultrasonografi yapıldı, patolojik bulguya rastlanmadı. Hastadan alınan öykü,yapılan fizik muayene, bakılan laboratuvar değerleri ve radyolojik tetkikler sonucunda ALP yüksekliği yapabilecek karaciğer, kemik ve barsak hastalıkları ile malignite düşünülmedi. Hastada benign geçici hiperfosfatazemi ön tanısı düşünülerek, ALP izoenzim paternleri gönderildi. Hastanın ALP izoenzim paterni sonucu; hastada karaciğer, kemik ya da barsak kaynaklı net bir izoenzim paterni saptanamadığı, atipik bir izoenzim paterni saptandığı, hastanın klinik ve laboratuvar ile birlikte değerlendirilip hastanın benign geçici hiperfosfatazya olabileceği şeklinde raporlandı. Hasta poliklinik takiplerine alındı. Hastanın ikinci ay kontrolünde bakılan ALP değerinin 190 IU/L seviyesine gerilediği izlendi (Tablo 1).

Tablo 1. Hastanın laboratuvar değerleri

\begin{tabular}{|c|c|c|c|c|c|c|c|c|c|c|c|c|c|}
\hline & $\mathbf{H b}$ & WBC & Plt & AST & ALT & $\mathbf{C a}$ & Mg & $\mathbf{P}$ & LDH & PTH & $\begin{array}{l}\text { Vit } \\
\text { D3 }\end{array}$ & TSH & ALP \\
\hline Başvuru & 12,4 & 8,530 & 343,000 & 47 & 27 & 9,8 & 2,07 & 5,7 & 225 & 41 & 43 & 1,52 & 4047 \\
\hline 1.kontrol & & & & & & 9,6 & & 6,0 & & & & & 1290 \\
\hline 2.kontrol & & & & & & & & & & & & & 190 \\
\hline
\end{tabular}

Hb:hemoglobin (9,6-13,1g/dl), WBC: lökosit (6,3-12,6 bin/mm3 ), Plt: trombosit (150-450 bin/mm3 ), AST: aspartat amino transferaz (10-48 U/L), ALT: alanin anino transferaz (5-25 U/L), Ca: kalsiyum (9-11 mg/dL ) Mg: magnezyum ( 1,7-2,2 mg/dL ), P: fosfor (3,4-6,2 mg/dL), LDH: laktat dehidrogenaz (180-430 U/L), PTH: parathormon (15-65 pg/mL), Vit D3: 25-Hidroksi vitamin D (20-120 ng/ml), TSH: tiroid st (0,7- 5,97 mIU/L), ALP: alkalen fosfataz $(<280 \mathrm{U} / \mathrm{L})$. 
ALP izoenzim paterni sonucu ve hastanın takiplerinde ALP düzeyinin tedavisiz azalarak normal sinırlara gerilemesi ile BGH tanısını netleşmiş oldu ve hastanın takipleri sonlandırıldı.

\section{Tartışma}

Alkalen fosfataz, yapısında çinko içeren, dört izoenzim paternine sahip olan glikopeptit yapısındaki enzimdir $(3,4)$. Tip 1 Karaciğer, kemik ve böbrek doku spesifik olmayan ; Tip 2 Plasental; Tip 3 Germ hücre ya da plasenta benzeri ; Tip 4 İntestinal kaynaklı

Serum ALP düzeyi yaşlara göre değişkenlik gösterebilmektedir. Özellikle ergenlik döneminde artmış büyüme hızı nedeniyle, gebelik döneminde fetal ve plesental yapıların üretimindeki artıştan dolayı 2- 3 kat artabilir $(4,5)$. Fakat hayatın hiçbir döneminde BHG'daki kadar artmaz.

BGH genellikle 5 yaşından küçük çocuklarda herhangi bir kemik veya karaciğer hastalığ1 olmaksızın, serum ALP düzeyinin normalin üst sınırına göre 3 kattan 50 kata kadar yüksekliği ile seyreden ve haftalar veya aylar içinde herhangi bir tedavi verilmeden ALP düzeyinin normal sınırlara gelmesi ile karekterize klinik durumdur $(1,2)$.

Çocuklarda geçici ALP yüksekliği ilk kez 1954 yılında Bach ve ark $(4,6)$ tarafindan bildirilmiş olup tanımlaması Posen ve ark (7) tarafindan 1977 yılında yapılmıştır. Kraut ve ark (8) tarafından ise 1985 yılında hastalığın 5 adet tanı kriteri ortaya konuldu.

1. ALP yüksekliğinin 5 yaş altında görülmesi,

2. Çeşitli ilişkisiz semptomların varlığı,

3. ALP izoenzimlerinin özellikle kemik ya da karaciğer kaynaklı olması,

4. Karaciğer ya da kemik hastalığ laboratuvar ya da klinik bulgu olmaması,

5. Ortalama 4 aylık bir sürede ALP düzeylerinin tedavisiz normal düzeye inmesi.

Hastalığın tanımı 5 yaş altı çocuklar için yapılmış olsa da 5 yaşından büyük çocuklarda ve nadiren yetişkinlerde de görülmüştür, en sık 2 yaş altında saptanır (9). Bizim olgumuzda 5 yaş altı olup şikayetler ile laboratuvar bulgularının ilişkisiz olması, karaciğer ve kemik hastalığına ait şikayet ve bulguların olmaması, tedavisiz ALP düzeyinin normal sınırlara gelmesi tanıyı desteklemiştir.

$\mathrm{Bu}$ hastalıkta genellikle karaciğer ve kemik kaynaklı ALP izoenzimleri yükselir, ince barsak izoenzimlerin yükseldiği daha az görülmüştür $(9,1)$.Ancak bizim hastamıda net olarak ALP izoenzim paterni tespit edilememiştir.
Hastalı̆̆ın patogenezinde; ALP'nin hücre içindeki artmış üretim,buna bağlı olarak artmış salınım ve plazmada yıkımının azalması düşünülse de BGH'nin nedeni tam olarak açıklanamamıştır (6). Hastalık mevsimsel olarak daha cok sonbahar ve kış aylarında görülse de ilkbaharda da olduğunu gösteren yayınlar bulunmaktadır $(1,4,10,11)$. Benign geçici hiperfosfatazemi prevelansı tam olarak bilinmemektedir ancak Asanti ve ark.'nın çalışmasında BGH prevelansı \%1.5 olarak saptanmıştır (13) .Genellikle kız ve erkeklerde eşit oranda görüldüğü bildirilmişse de erkeklerde biraz daha sık görüldüğüne dair yayınlar da mevcuttur $(14,15)$. Hastalığın nedenleri arasında, gastrointestinal sistem hastalıkları, solunum sistemi hastalıkları ve anemi birlikteliği gösterilmiş, özellikle son zamanlarda virüslerin etiyolojide rolü olabileceği düşünülmüştür $(1,6,12,16)$. Bizim hastamız da gastrointestinal şikayetlerle başvurmuş ve ALP yüksekliği rastlantısal olarak saptanmıştır. Hastalığın sonbahar ve kış dönemlerinde artması viral etkenlerin etyolojide rol alabileceği görüşünü desteklemektedir.

Benign geçici hiperfosfatazeminin ayırıcı tanısında karaciğer, kemik hastalıkları, maligniteler ekarte edildikten sonra kronik idiopatik hiperfosfatazemi ve selim ailesel hiperfosfatazemi ile ayırıcı tanısı yapılmalıdır. Bizim hastamızda periferik yaymada atipik hücrenin olmaması, hastanın batın ultrasonografisinin normal olması, ateş, iştahsızlık, kilo kaybı gibi şikayetlerin olmaması, laboratuvar tetkiklerinde ALP yüksekliği dışındaki değerlerin normal sınırlarda olması ve ALP seviyesinin takiplerde gerilemeye başlaması nedeniyle kemik iliği aspirasyonu gibi ileri tetkikler yapılmasına ihtiyaç duyulmamış ve hastada malignite düşünülmemiştir. Kronik idiyopatik hiperfosfatazemi çocuklarda nadir görülen, yaygın, simetrik, ilerleyici kemik deformitelerinin olduğu, serum ALP ve idrar hidroksiprolin düzeylerinde artış saptanan jeneralize bir iskelet displazisidir $(17,18)$. Selim ailesel hiperfosfatazemi ise otozomal dominant geçiş gösterir ve serum ALP yüksekliğinin devam etmesi ile karakterizedir (19).Bizim hastamızda kemik hastalılarına ait şikayet ve bulguların olmaması, büyüme ve gelişmesinin normal olması, aile hikayesinin olmaması, sol el bilek grafisinin normal olması ve tedavisiz laboratuvar bulguların düzelmesi ayırıcı tanıda bu hastalıklardan uzaklaştırmıştır.

BGH çoğunlukla 5 yaş altı çocuklarda laboratuvar bulgularıyla ilişkisiz klinik bulguları olan, rastlantısal olarak saptanan ve tedavisiz düzelen klinik durumdur. ALP yüksekliği ile 
başvuran hastalarda karaciğer, kemik hastalıkları ve maligniteler ekarte edildikten sonra BGH tanıda ve ayrıcı tanıda akla gelmelidir. ALP yüksekliği ile başvuran klinik olarak ilişkisiz semptomları olan hastalarda BGH tanısı ayric1 tanıda akılda bulunmalıdır ki bu durum; hastalarınüst merkezlere sevk edilip sağlık maliyetlerinin artmasının önüne geçerek, sağlık harcamalarını azaltacaktır.

Yazarlar arasında herhangi bir çıkar çatışması bulunmamaktadır.

\section{References}

1. Huh SY, Feldman HA, Cox JE, Gordon CM. Prevalence of transient hyperphosphatasemiaamonghealthyinfantsandtoddl ers. Pediatrics 2009;124:703-9.

2. Teitelbaum JE, Laskowski A, Barrows FP. Benign transient hyperphosphatasemia in infantsandchildren: A prospectivecohort. J Pediatr EndocrinolMetab 2011;24:93-5.

3. Candemir M, Özdemir MA, Ergin H. Bir vaka nedeniyle selim geçici hiperfosfatazemi. Furat Tıp Derg 2008;13:74-6.

4. Tolaymat N, de Melo MC. Benign transient hyperphosphatasemia of infancyand childhood. South Med J 2000;93:1162-4.

5. Eymann A, Cacchiarelli N, Alonso G, Llera J. Benigntransient hyperphosphatasemia of infancy. A commonbenignscenario, abigconcernfor a pediatrician. J Pediatr EndocrinolMetab 2010;23:927-30

6. Arıkan Ç, Arslan M, Tümgör G, Çakır M, Aydoğdu S. Çocukluk çağı benign geçici hiperfostazemisi. Güncel Pediat 2007;5:96-8.

7. Posen S, Lee C, Vines $\mathrm{R}$, et al. Transienthyperphosphatasemia of infancy--an insufficientlyrecognizedsyndrome. ClinChem 1977;23:292-4.

8. Kraut JR, Metrick M, Maxwell NR, Kaplan MM. Isoenzymestudies in transienthyperphosphatasemia of infancy. Ten newcasesand a review of theliterature. Am J Dis Child 1985;139:736-40.

9. Kutilek S, Cervickova B, Bebova P, Kmonickova $\mathrm{M}$, Nemec V. Normal bone turnover in transienthyperphosphatasemi. J ClinRes Pediatr En docrinol 2012;4:154-6.
10. Eboriadou M, Skouli G, Panagopoulou P, Haidopoulou K, MakedouA, Varlamis G. Acute laryngotracheobronchitis and associated transienthyperphosphatasemia: A newcase of transient hyperphosphatasemia in earlychildhood. J Paediatr Child Health2006;42:149-50.

11. Suzuki M, Okazaki T, Nagai T, Törõ K, Sétonyi P. Viralinfection of infantsandchildren with benign transien thyperphosphatasemia.FEMS ImmunolMedMicrobiol 2002;33:215-8.

12.Crofton PM. What is thecause of benigntransienthyperphosphatasemia? A study of 35 cases. ClinChem 1988;34:335-40.

13. Asanti R, Hultin H, Visakorpi JK. Serum alkaline, phosphatase in healthyinfants. Occurrence of abnormallyhighvalueswithoutknowncause. AnnPaediatrFenn 1966;12:139-42.

14. Carrol AJ and Coakley JC. Transienthyperphosphatasaemia: An important condition torecognize. J Paediatr Child Health2001;37:359-362.

15. Behulova D, Bzduch V, Holesova D, Vasilenkova A, Ponec J.Transient hyperphosphatasemia of infancyandchildhood:study of 194 cases. ClinChem2000;46:18681869.

16. Otero JL, Gonzalez-Peralta RP, Andres JM, et al. Elevated Alkaline Phosphatase in Children: An AlgorithmtoDetermineWhen a "WaitandSee" Approach is Optimal. ClinMedInsights Pediatr 2011;5:15-8.

17. Antoniades K, Karakasis D, Kapetanos G, Lasaridis N,Tzarou V. Chronic idiopathic hyperphosphatasemia. Case report. Oral Surg Oral Med Oral Pathol1993;76:200-204.

18. Dundar B, Turedi A, Comak E. Selim gecicihiperfosfatazemili bir vaka. Çocuk Dergisi 2005;5:66-67.

19. Siraganian PA, Mulvihill JJ, Mulivor RA, Miller RW. Benign familialhyperphosphatasemia. JAMA 1989;261:1310-1312. 